\title{
Value Creation Through Social Strategy
}

\section{Bryan W. Husted, David B. Allen, and Ned Kock}

\begin{abstract}
Literature on corporate social responsibility (CSR) has tended to treat economic benefits to the firm as unintentional spillovers that result from laudable CSR behavior. Empirical studies of the relationship between $\mathrm{CSR}$ and corporate financial performance (CFP) have reported mixed findings. This article shifts the conceptual and empirical focus to investigate the conditions under which intentional profit-seeking through corporate social action projects can create economic value for the firm. The article uses resourcedependency theory and the resource-based view to define the firm's external and internal environments respectively. From that perspective, the article looks at how corporate social action creates economic value through strategic social planning and strategic social positioning. A survey instrument was developed and applied to 110 large Spanish firms. In that sample, munificence and continuous innovation positively affect social positioning, while nongovernmental organization salience and social responsibility orientation positively affect social planning. Both social positioning and social planning in turn contribute to corporate ability to create value. The article concludes with a discussion of the research and managerial implications of these findings.
\end{abstract}

\section{Keywords}

corporate social responsibility, resource-based view, resource dependency, value creation

Over the past 25 years, business and society scholars have attempted to establish a business case for corporate social responsibility (CSR). One study defines CSR as "actions that appear to further some social good, beyond the interests of the firm and that which is required by law" (McWilliams \& Siegel, 2001, p. 117). This search for a business case has proceeded by examining the impact of CSR on corporate financial performance (CFP) in the hope of demonstrating that firm commitment to CSR is good for business, either in terms of accounting profits or improved market valuation (Cochran \& Wood, 1984; Griffin \& Mahon, 1997; Margolis \& Walsh, 2001; McWilliams \& Siegel, 2000; Orlitzky, Schmidt, \& Rynes, 2003; Waddock \& Graves, 1997). To date, the results of these 
studies of CSR and CSP have been mixed at best. Attempts to establish a causal relationship between CSR and CFP are confounded by both the large number of moderating variables that influence the CSR-CFP relationship and the mediating variables that intervene in the process between CSR activities and corporate financial results (Rowley \& Berman, 2000).

In this article, the authors shift conceptual and empirical focus to ask a different question, which seeks to understand the conditions under which corporate social action can create value for the firm. Accordingly, this article modifies the CSR-CFP debate in three ways. First, building on prior work by Husted and Allen (2007), it focuses on the conditions under which intentional profit-seeking through corporate social action projects can create economic value for the firm. Second, it moves the conversation away from the contested concept of CSR with its normative underpinnings to the more instrumental concept of social strategy. The former conversation simply examines whether and how CSR is linked to CFP, while the latter suggests that firms develop social strategies, which consist of a portfolio of social action projects. Third, the article broadens the focus of performance from financial results to value creation, which deals with the recombination of resources in new ways to increase the productivity of those resources (Moran \& Ghoshal, 1999; Schumpeter, 1934).

Despite the difficulties in the current discussions, enthusiasm for CSR has not dampened. Investors have committed to CSR via ethical investment funds (e.g., The Calvert Funds and Bloomberg's Environmental, Social and Governance [ESG] Data Service), while firms worldwide have increased expenditures and active engagement (e.g., increased philanthropy and employee community involvement programs). In support of these well- intentioned efforts, academics continue to insist, despite shaky evidence, that CSR is positively related to competitive advantage and firm financial performance. Recent articles claim that CSR activities such as philanthropy can be managed to build organizational moral capital (Godfrey, 2005) and that markets can be segmented to assure that customers sharing a company's moral values are aware of its social performance (Schuler \& Cording, 2006).

However, these economic benefits are treated as unintentional spillovers that result from laudable CSR behavior. This research continues to leave unresolved a fundamental antecedent question concerning whether it is possible to reconcile CSR with intentional profit-seeking via social action projects. Many business firms choose a CSR agenda that conforms to the traditional approach by selecting projects and meeting social obligations and objectives irrespective of firm interest. Projects are approved because there is a budget for them. Should there be competitive benefits, they are simply the 
result of doing good things.

In contrast, a strategic approach to corporate social activity, as opposed to simply doing well by doing good, requires that companies create and implement social projects that seek competitive advantage and economic value (Grant, 2006; Porter, 1985), replicating the strategic intention of "market" behavior. Accordingly, in this article, the authors' objective is to specify under what conditions social projects can be strategic. The article operates in the realm of instrumental CSR (Garriga \& Mele, 2004) by developing and testing a framework for linking social projects to value creation. The article begins, then, with the proposition that a positive relation- ship between social action and financial performance is more likely to be found when executives design one or more social projects in ways that seek to create competitive advantages for the firm (Burke \& Logsdon, 1996).

Such intentional, designed profit-seeking through social action is termed "social strategy," leaving intact the ethical approaches to CSR to include those social initiatives undertaken by firms that legitimately do not seek to generate profits, but only to further some social good (Garriga \& Mele, 2004). Social strategy shares with business strategy the pursuit of profit, but it is not simply a specific kind of business strategy. Social strategy requires the integration of strategic business and strategic social actions. In very practical terms, business strategies employ firm resources and capabilities to achieve purely market-based competitive objectives independent of social outcomes. Social strategy applies firm resources and capabilities to meet both social objectives and financial performance objectives. In sum, social strategy must fulfill the dual demands of furthering a social good and value creation superior to that of other available projects.

Explaining how social strategy may create value is one of the principal challenges of this article. It argues that value creation via social strategy is a result of the fit between the firm's social positioning and social planning and four sets of variables defined by the external environment, including market and nonmarket stakeholders and the firm's internal environment, including resources and values (Andrews, 1987). Without taking into account the relationship between these variables and the use of social positioning and social planning, the link between corporate social projects and CFP will remain obscure.

The rest of this article is structured as follows. The next section sets out the theoretical basis by defining social strategy in terms of the strategic management literature, specifically through the concepts of strategic planning and strategic positioning. In the following section, the authors then develop hypotheses linking social positioning to markets characterized by high dynamism and high 
munificence as well as firm resources for stake-holder integration and continuous innovation. Additional hypotheses relate social planning to the nonmarket environment of salient stakeholders and corporate values. The final group of hypotheses relates both social position- ing and social planning to value creation. The subsequent section explains the methods used to survey 110 large Spanish firms and test the hypotheses using the statistical method of partial least squares (PLS). The next sections report the results, followed by a discussion of the results. The concluding section explores directions for future research and the managerial implications of the findings.

\section{Theoretical Basis for Testable Hypotheses}

Given the extensive terminology introduced to help understand social strat- egy, Table I provides definitions to guide readers through the new terms.

\section{Value Creation}

The framework shifts the focus of the dependent variable from financial performance to value creation. Value simply refers to the worth of some product or service to the consumer. A firm creates value by combining its resources innovatively to increase the productivity of those resources (Moran \& Ghoshal, 1999; Schumpeter, 1934). In the case of social action,

Table 1. Definitions

\begin{tabular}{|l|l|l|}
\hline Term & Definition & Source \\
\hline Social Project & $\begin{array}{l}\text { A combination of human } \\
\text { and nonhuman resources } \\
\text { organized temporarily to } \\
\text { achieve a specific social } \\
\text { objective }\end{array}$ & Cleland and King (1988) \\
\hline Social Strategy & $\begin{array}{l}\text { Portfolio of intentional, } \\
\text { profit-seeking social } \\
\text { projects }\end{array}$ & Authors \\
\hline Value Creation & $\begin{array}{l}\text { Combination of resources } \\
\text { in new ways in order to } \\
\text { increase the productivity of } \\
\text { those resources }\end{array}$ & $\begin{array}{l}\text { Moran and Ghoshal (1999); } \\
\text { Schumpeter (1934) }\end{array}$ \\
\hline Planning & $\begin{array}{l}\text { Defining a program and } \\
\text { agenda for action, including } \\
\text { the investment of financial } \\
\text { and human resources, and } \\
\text { the measurement of } \\
\text { outcomes }\end{array}$ & Andrews (1987) \\
\hline Positioning & $\begin{array}{l}\text { Extent to which firms are } \\
\text { proactive in responding to } \\
\text { social issues vis-à-vis their }\end{array}$ & $\begin{array}{l}\text { Clarkson (1995); Meznar } \\
\text { and Nigh (1995) }\end{array}$ \\
\hline
\end{tabular}




\begin{tabular}{|l|l|l|}
\hline & competitors & \\
\hline Dynamism & $\begin{array}{l}\text { The perceived difficulty in } \\
\text { predicting external events } \\
\text { that may affect the } \\
\text { competitive environment }\end{array}$ & $\begin{array}{l}\text { Aldrich (1979), Delmas, } \\
\text { Russo, and Montes-Sancho } \\
\text { (2007) }\end{array}$ \\
\hline Munificence & $\begin{array}{l}\text { Availability of resources to } \\
\text { support growth }\end{array}$ & $\begin{array}{l}\text { Castrogiovanni (1991, } \\
\text { 2002); Dess and Beard } \\
\text { (1984); Koka, Madhaven, } \\
\text { and Prescott (2006); Staw } \\
\text { and Szwajkowski (1975) }\end{array}$ \\
\hline Stakeholder Salience & $\begin{array}{l}\text { "The degree to which } \\
\text { managers give priority to } \\
\text { competing stakeholder } \\
\text { claims" }\end{array}$ & $\begin{array}{l}\text { Mitchell, Agle, and Wood } \\
\text { (1997, p. 854) }\end{array}$ \\
\hline $\begin{array}{l}\text { Stakeholder } \\
\text { Integration }\end{array}$ & $\begin{array}{l}\text { "The ability to establish } \\
\text { trust-based collaborative } \\
\text { relationships with a wide } \\
\text { variety of stakeholders" }\end{array}$ & $\begin{array}{l}\text { Sharma and Vredenburg } \\
\text { (1998, p. 735) }\end{array}$ \\
\hline $\begin{array}{l}\text { Continuous } \\
\text { Innovation }\end{array}$ & $\begin{array}{l}\text { Ability to experiment and } \\
\text { continuously improve social } \\
\text { projects, impacts, and } \\
\text { stakeholder relationships }\end{array}$ & $\begin{array}{l}\text { Hart (1995); Sharma and } \\
\text { Vrendenburg (1998) }\end{array}$ \\
\hline $\begin{array}{l}\text { Social Responsibility } \\
\text { Orientation }\end{array}$ & $\begin{array}{l}\text { A company's commitment } \\
\text { to participating in the } \\
\text { solution of social problems }\end{array}$ & $\begin{array}{l}\text { Goll (1991); Goll and } \\
\text { Sambharya (1995) }\end{array}$ \\
\hline $\begin{array}{l}\text { Participative Decision } \\
\text { Making Orientation }\end{array}$ & $\begin{array}{l}\text { A proactive search for } \\
\text { opportunities, participation, } \\
\text { analytic decision tools, } \\
\text { open communication } \\
\text { channels, and participative } \\
\text { consensus-based decision } \\
\text { making }\end{array}$ & Goll and Sambharya (1995) \\
\hline
\end{tabular}

activities that engage social issues can also be combined with firm resources in ways that will create value for the firm. In most cases, created value is captured by the firm when consumers pay an additional sum for the firm's products and services based on its participation in projects related to specific social issues. Value may also be created when new and/ or more efficient processes, products, and services emerge from social action projects. In both cases, the captured value then leads to increased financial performance as measured by accounting-based and market- based indicators.

\section{Social Strategy}

The basic unit for social action is the social project, which has been defined as a combination of human and nonhuman resources organized temporarily to achieve a specific social objective (Cleland \& King, 1988). Social strategy comprises a portfolio of social projects organized with the purpose of creating value for the firm. Although some thinkers have argued that business strategy may be deliberate or emergent (Ansoff, 1991; Mintzberg, 
1990), the approach to social strategy taken by this article includes only those strategies where firms deliberately design projects and measure strategic investment and outcomes, while excluding those where firms do not (Liedtka, 2000).

The concept of strategy was originally developed in a military context and later applied to business and other activities. Taking into account these multiple contexts, Robert Grant defines strategy broadly as "the overall plan for deploying resources to establish a favorable position" (Grant, 1999, p. 14). His definition of strategy includes two broad components: plan and position. Similarly, social strategy requires elements of both planning and positioning.

Strategic planning involves determining long-term goals, actions to achieve those goals, and the allocation of resources to carry out those actions (Chandler, 1962; Grant, 1999; Quinn, 1980). Firms may be said to engage in strategic social planning based on the importance given to (a) defining a pro- gram and agenda for social action, (b) intensity of investment in social pro- grams, (c) commitment of employees, and (d) measuring outcomes of programs (Husted \& Allen, 2007). These operational elements are derived from Andrews (1987), who emphasizes the centrality of the planned application of resources and the vital role of employees in developing organizational knowledge central to strategy initiatives (Grant, 1996). Just as in traditional strategic planning (Grant, 1999, pp. 401-404), the measurement of the outcomes of social projects is key to ensuring that such projects are being managed within a strategic planning process (Daniel, 1992; Kaplan \& Norton, 1996).

Social positioning refers to the extent to which firms are proactive in responding to social issues vis-à-vis their competitors (Clarkson, 1995). Strategic social positioning is present when a firm differentiates itself from the competition with respect to social issues (Delmas, Russo, \& Montes- Sancho, 2007). This differentiation occurs by (a) being first to adapt corporate practices to changing social expectations; (b) exceeding current regulatory norms; and (c) spending more on social projects than the competition. The operational elements for strategic social positioning adapt traditional strategy features such as first-mover advantage (Lieberman \& Montgomery, 1988), market differentiation (Porter, 1980, 1985), and resource differentiation (Barney, 1991) as well as social initiative (Meznar \& Nigh, 1995). Wal-Mart's heralded "packaging scorecard," reducing environmental impacts and consumer prices, amply meets these criteria.

As corporate market behavior has become more complex, definitions of strategy must reconcile earlier approaches that focused almost exclusively on planning with later approaches that focus on positioning to create competitive advantage. Of course, one would expect there to be some correlation between planning and positioning. 
In sum, though they are not the same, neither are they mutually exclusive. Effective strategic action requires understanding the difference, the relationship between the two, and when a firm may wish to give priority to one or the other.

Developing a social strategy plan is an indication that the firm perceives significant opportunity or risk in the nonmarket environment. However, this is just the first step. To demonstrate strategic intent (Hamel \& Prahalad,

1989), it is necessary to show that the firm manages firm resources and policies (e.g., attention given to key stakeholders) with the objective of creating a unique competitive position. Hence the focus on both planning and positioning as ways to develop social strategy intentionally. Depending on the environment, a firm is likely to emphasize one or the other, though both planning and positioning may be employed to create economic value via social projects.

Accordingly, social strategy incorporates traditional strategy concerns of strategic planning and strategic positioning determined by firm evaluation of external opportunities and threats and internal strengths and weaknesses (Andrews, 1987; Barney, 1991). Resource-dependency theory frames the approach to the external environment in this article (Pfeffer \& Salancik, 1978), while the resource-based view of the firm shapes the approach to the firm's internal environment (Peteraf, 1993; Wernerfelt, 1984). 


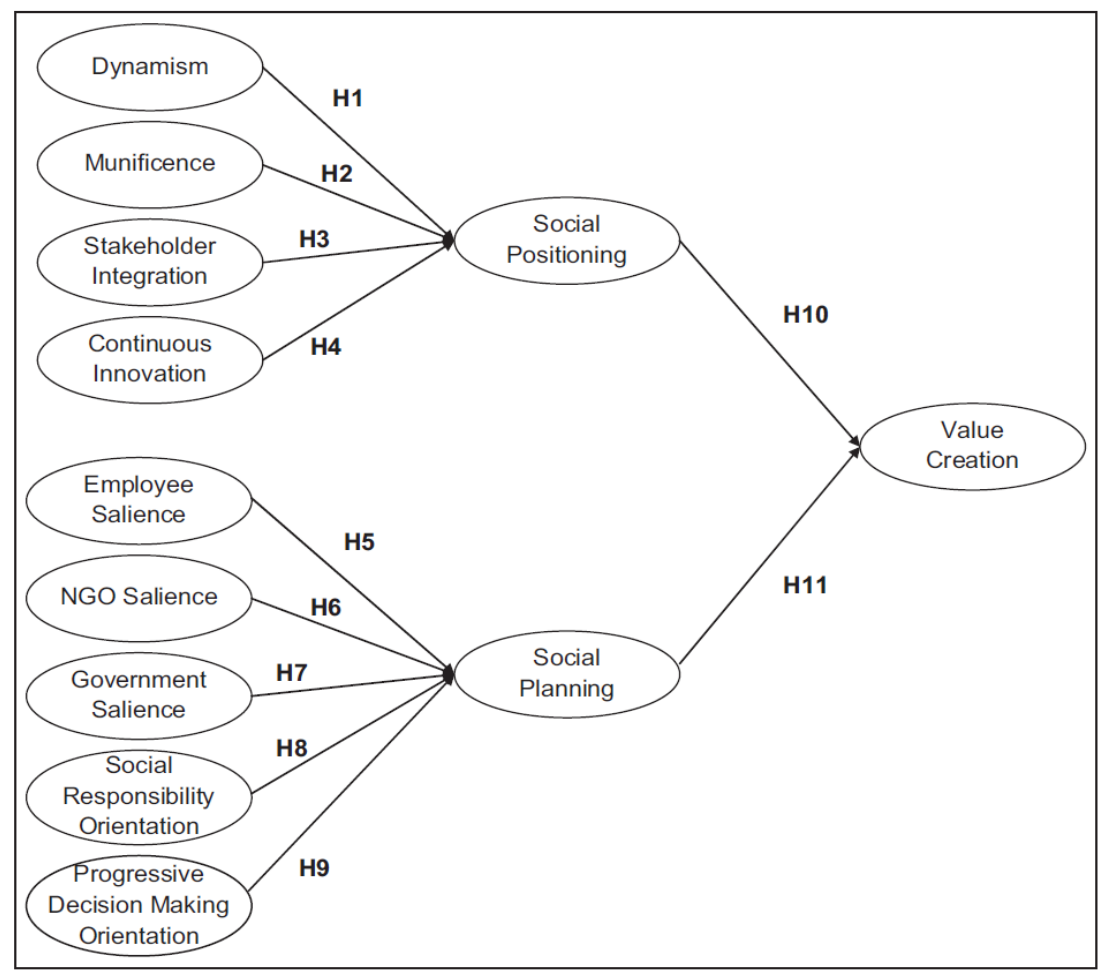

Figure I. Structural model

\section{Hypothesis Development}

The development of hypotheses begins by looking at the external and internal antecedents of social positioning, specifically the industry environment and the firm's resources and capabilities. Then, the focus shifts to social planning and its external and internal antecedents, particularly the salience of nonmarket stakeholders and the firm's values. Finally, social positioning and social planning are hypothesized to influence firm value creation. Figure 1 joins these hypotheses into a single model of the relationships among the variables and provides a visual display of the development of the hypotheses that follows. 


\section{Social Positioning}

Industry environment. For social strategists, understanding and measuring industry structure requires a complex view of firm environment in which managers assess their ability to build competitive advantage as they acquire and manage resources. According to resource dependency theory, managers develop strategies in response to their need to compete for scarce resources (Dess \& Beard, 1984; Pfeffer \& Salancik, 1978). The approach taken in this article is to analyze top management perceptions of the industry environment through two fundamental variables developed in the environmental analysis literature: dynamism and munificence (Castrogiovanni, 1991, 2002; Dess \& Beard, 1984; Keats \& Hitt, 1988; Sutcliffe \& Huber, 1998).

Dynamism measures the perceived rate of change and degree of difficulty in predicting external events that may impact the industry environment (Aldrich, 1979). Creating economic value in highly unstable competitive market environments is difficult and expensive (Miller, 1987; Miller \& Friesen, 1983), largely because investments in unique resources are much riskier. In such environments, planning is problematic given the inability to predict the impacts of external events on firm value creation. Consequently, firms in highly dynamic market environments are more likely to position themselves with respect to social issues relative to competitors as a means of bolstering reputation and winning the support of customers and other stakeholders who control valuable resources. Customer reputation (market legitimacy) protects firms from the uncertainties they confront in dynamic environments (Goll \& Rasheed, 2004). Moreover, there is evidence that social and environmental reputations are easier to build in dynamic markets than in stable markets because the entrants and industry norms are in a state of flux (Delmas et al., 2007). In sum, in dynamic markets social positioning provides the firm with a rapid and flexible means of differentiation with respect to competitors.

Hypothesis 1: The higher the dynamism of an industry, the greater the strategic social positioning of the firm.

Munificence refers to the availability of resources to support growth (Castrogiovanni, 1991, 2002; Dess \& Beard, 1984; Koka, Madhaven, \& Prescott, 2006; Staw \& Szwajkowski, 1975). Researchers have found that firms, especially new entrants and entrepreneurs, are more likely to engage in innovation and to seek objectives, other than survival, in environments characterized by 
high munificence (Castrogiovanni, 1991, 2002; Tushman \& Anderson, 1986). In contrast, firms in environments characterized by low munificence are more likely to engage in illegal activity (Staw \& Szwajkowski, 1975) as a substitute for innovation and differentiation. One clear example of the process of social positioning and innovation, followed by imitation, occurred in the energy industry where, in a munificent environment, British Petroleum (BP) took on a social positioning to differentiate itself from other, even larger competitors.

It is necessary to keep in mind that even in a munificent environment, a particular resource, such as human capital, may be scarce. Sherer and Lee (2002) studied how a large law firm responded to scarce human capital by investing in organizational innovation, which was quickly imitated by competitors in its organizational field.

Management of the relationship between the external environment (resource dependency) and firm resources is at the very core of strategy. Prior to the development of complex competitive RBV models based on "dynamic resources" (Teece, Pisano, \& Shuen, 1997), strategy formulation was treated as an analysis of the firm's strengths, weaknesses, opportunities, and threats (SWOT). Firms sought to match their strengths to market opportunities and acquire the necessary resources while avoiding market threats and protecting the firm from internal weaknesses.

Despite theoretical and methodological advances in fields such as the resource-based view and resource dependency, the basics of strategy, as Grant (1999) and Porter (1980, 1985) have vigorously argued for over two decades, remain the same. Firms must either develop resources internally or acquire them from the external environment to achieve differentiation and create superior value. In this section on external environment, it is argued that social positioning draws on munificent environments to build firm differentiation (often reputation) with market stakeholders. Thus, social positioning is more likely to occur in the presence of environmental munificence because of the greater availability of resources to innovate and differentiate the firm. Hence, it is proposed:

Hypothesis 2: The higher the munificence of an industry, the greater the strategic social positioning of the firm.

Firm resources and capabilities. Defining firm resources has proved to be quite controversial (Priem \& Butler, 2001). According to Jay Barney (1991, p. 101), resources refer to "all assets, capabilities, organizational processes, firm attributes, information, knowledge, etc., controlled by the firm that enable the firm to conceive of and 
implement strategies that improve its efficiency and effectiveness...." This definition comprehends the widely diverse resources firms may use to create economic value and competitive advantage. Although possessing resources that are rare, valuable, and inimitable is a necessary condition for a firm to maintain a sustainable competitive advantage, strategic deployment of these resources is frequently necessary. Usually, an array of resources must be combined to create higher level capabilities that enable firms to sustain a competitive advantage (Sharma \& Vredenburg, 1998; Teece et al., 1997).

Intangible resources and capabilities play a central role in designing and executing effective social strategy, which generates benefits through corporate reputation, employee motivation, and customer loyalty. Each of these intangible resources is based on a dynamic relationship that evolves over time as the firm collaborates with its market and nonmarket stakeholders. The deployment of these resources and capabilities to exploit both business and social opportunities helps to create a strategic social positioning for each firm (Eisenhardt \& Martin, 2000) among networks of stakeholder relationships (Koka et al., 2006). Two capabilities are especially relevant to the development of strategic social positioning: stakeholder integration and continuous innovation.

First, the integration of multiple stakeholders needs to take place when important stakeholders (employees, customers, community organizations, perhaps even government regulatory agencies) directly interact with each other. For the firm, the capability of stakeholder integration refers to "the ability to establish trust-based collaborative relationships with a wide variety of stakeholders" (Sharma \& Vredenburg, 1998, p. 735).

Effective stakeholder integration makes the use of strategic positioning more likely as the firm is sensitive to the interrelatedness of its stakeholders. Research indicates that effective collaboration with stakeholders generates significant economic benefits for firms (Preston, Post, \& Sachs, 2002). For example, a supplier may work with the firm in project teams that seek to make the supply chain eco-efficient. Such joint action may induce innovation that reduces costs for both firms. The social issues that arise in such situations are complex and often need the participation of diverse stakeholders (Porter \& Kramer, 2011). Firms that know how to engage their stakeholders effectively through dialogue and joint problem solving are more likely to achieve a strategic social positioning.

Hypothesis 3: The greater the degree to which a firm possesses the capability of stakeholder integration, the greater the strategic social positioning. 
The capability of continuous innovation also plays a key role in obtaining a strategic social positioning. Both process and product innovations are vital to creating social and economic value for firms in competitive markets (Orsato, 2006). Hart (1995) originally wrote of "continuous improvement" in relation to the impact of total quality management capabilities on environ- mental management. This article follows Sharma and Vredenburg (1998) by using the term "continuous innovation" and adapts it to refer to the firm's ability to experiment and continuously improve social projects, impacts, and stakeholder relationships. Such innovation enables the firm to obtain a mar- ket position as a cost leader or product differentiator (Porter, 1980).

Growing research confirms the tight link between research and development and corporate social responsibility (McWilliams \& Siegel, 2000; Porter \& Kramer, 2011). The direction of the causality appears to be two- way. On the one hand, firms can use social objectives to motivate product and process innovation (Hart \& Sharma, 2004; Kanter, 1999). General Electric (GE)'s Healthymagination and Ecomagination initiatives represent the investment of billions of dollars in research and development in order to achieve social and environmental objectives. Furthermore, social and environmental programs may stimulate the development of competitively valuable resources and capabilities for the firm (Sharma \& Vredenburg, 1998). On the other hand, firms that possess a capability for continuous innovation in developing new products and services for the market are more likely to use that same capability in other arenas, such as its positioning with respect to changing social expectations and issues in ways that will allow the firm to create economic value.

Hypothesis 4: The greater the degree to which a firm possesses the capability of continuous innovation, the greater the strategic social positioning.

\section{Social Planning}

Nonmarket stakeholders. The core of stakeholder theory has been described as the management of "potential conflict stemming from divergent interests" (Frooman, 1999, p. 193). Freeman (1984, p. 46) defines stakeholders as all persons or groups that "can affect or [are] affected by the achievement of an organization's objectives." Although the definition of stakeholder remains highly contested (Mitchell, Agle, \& Wood, 1997), these stakeholders form the social 
context in which firms do business and help define the firm's social responsibilities. The relations among stakeholders with conflicting interests generate the opportunities and threats with respect to which firms need to respond through the plans they develop. Managerial attention and the firm's subsequent response to a given stakeholder are contingent on its salience (Henriques \& Sadorsky, 1999).

Stakeholder salience is defined as "the degree to which managers give priority to competing stakeholder claims" (Mitchell et al., 1997, p. 854). Salience depends on the stakeholder's power and legitimacy as well as of the urgency of its claims (Mitchell et al., 1997). Resource dependency theory focuses on stakeholder power, which is a function of the firm's need for strategic resources controlled by the stakeholder (Frooman, 1999; Pfeffer \& Salancik, 1978) and the network of stakeholder relations (Rowley, 1997). Research indicates a significant statistical relationship between power, legitimacy, and urgency on the one hand and stakeholder salience on the other (Agle, Mitchell, \& Sonnenfeld, 1999).

Powerful stakeholders pose both an opportunity for collaboration and a potential threat to the firm (Savage, Nix, Whitehead, \& Blair, 1991). As the power of a stakeholder group grows, firms tend to cooperate by working jointly with the stakeholder as an ally or to decrease their reliance on that stakeholder (Freeman, 1984; King, 2007; Savage et al., 1991).

Strategic social planning is possible in situations characterized by highly salient stakeholders that have the capacity to collaborate with the firm or threaten it (Freeman, 1984; King, 2007; Savage et al., 1991). Such stakeholders include civil-society organizations, employees, and governments, among others. In these situations, the firm and its stakeholders negotiate in order to find "win-win" solutions (Frooman, 1999). For exam- ple, nongovernmental organizations (NGOs) represent a variety of inter- ests that make claims upon large firms. These requests can create significant constraints for CFP by increasing costs for the firm (Palmer, Oates, \& Portney, 1995). When NGOs influence access to strategic resources, particularly social capital and legitimacy, they may endanger the firm's strategic plans. The firm can best respond by developing long-term relationships in ways that create intangible, valuable assets for the firm (Hillman \& Keim, 2001; King, 2007). By focusing on long-term relationships, firms demonstrate commitment through plans that involve the investment of resources, rather than through its position with respect to social issues, which may necessarily shift over time. The same logic applies to other, highly salient stakeholders like employees and the government, whose support is vital to sustaining the firm's legitimacy and social capital. Thus it is hypothesized 
Hypothesis 5: The greater the salience of employees, the greater the strategic social planning of the firm.

Hypothesis 6: The greater the salience of NGOs, the greater the strate- gic social planning of the firm.

Hypothesis 7: The greater the salience of government stakeholders, the greater the strategic social planning of the firm.

Corporate values and ideology. Andrews (1987) originally included corporate values as one of the fundamental pillars of corporate strategy, alongside the market environment and firm resources. This focus on values was then set aside in Porter's work on industry structure $(1980,1985)$. Barney (1986) argued, however, that corporate culture is a kind of firm resource and can be a source of competitive advantage. As components of firm culture, values and business philosophy or ideology are also potential resources of the firm; values are essential to a firm's identity (Albert \& Whetten, 1985 ) and to its commitment to noneconomic objectives within its mission and strategy. Clearly, values and CSR are excellent candidates for examination from the perspective of the resourcebased view (Barney, Wright, \& Ketchen, 2001).

Kluckhohn and his colleagues (Kluckhohn, 1951, p. 395) have defined a value as "a conception, explicit or implicit, distinctive of an individual or characteristic of a group, of the desirable which influences the selection from available modes, means, and ends of action." These values, joined together in different configurations, form the essence of a group's culture.

Ideology is a subset of culture, which includes the explicit or formal values of the group (Geertz, 1973; Pettigrew, 1979). Corporate ideology has been defined as "shared, relatively coherently interrelated sets of emotionally charged beliefs, values, and norms that bind some people together and help them to make sense of their worlds" (Trice \& Beyer, 1993, p. 33). It has also been referred to as business or managerial philosophy (Alvesson

\& Berg, 1992) and includes the stated values of the firm that shape its perception of the business and its environment.

Corporate values are susceptible to a RBV treatment given that they are appropriately valuable, rare, inimitable, and subject to the firm's organizational capability to take advantage of these values. Considerable evidence indicates that ethical values and CSR can be valuable for firms (Orlitzky et al., 2003). However, such cultures among firms are rare as demonstrated by the constant calls for ethical and socially responsible behavior. Although the trappings of ethical codes are easy to imitate, corporate culture is much more difficult to emulate (Barney, 1986). Even where firms develop the resource of a strong cultural commitment to ethics, the ability to 
benefit strategically is likely to vary considerably.

Corporate ideology affects strategic planning by helping to channel avail- able firm responses to opportunities and threats. Specifically, ideology shapes the formulation and implementation of strategic plans by influencing the manager's evaluation of the environment by limiting his or her vision through processes of selective perception (Goll \& Sambharya, 1995). Corporate ideology is related to strategy, financial performance, and social responsibility because these explicit values affect the decisions made by managers based on their goals, objectives, and beliefs about how the world works (Prahalad \& Bettis, 1986; Simons \& Ingram, 1997).

Corporate ideologies, and their attendant values, can either support or undermine firm commitment to supporting social action. Clearly some are more likely to produce a commitment to social action than other ideologies. There is evidence that at least two dimensions of corporate ideology are relevant to strategic social planning: social-responsibility orientation and participative decision making (Goll \& Zeitz, 1991).

Social responsibility orientation refers to a company's commitment to participating in the solution of social problems (Goll, 1991; Goll \& Sambharya,

1995). It guides how managers respond to stakeholder threats and opportu- nities and has a significant impact on firm social performance (Muller \& Kolk, 2010). Social responsibility orientation constitutes a set of values that provides a barrier to imitation by the firm's rivals (Barney, 1986; O'Reilly

\& Pfeffer, 2000; Reinhardt, 1999). Social responsibility orientation is valued by some consumers, who are willing to pay a premium for goods with social attributes (Berman, Wicks, Kotha, \& Jones, 1999; Maignan, Ferrell, \& Hult,

1999; Menon \& Menon, 1997; Reinhardt, 1999; Schuler \& Cording, 2006). Without an unambiguous commitment to social responsibility, the firm would be unable to formulate strategic plans to meet its social objectives.

Hypothesis 8: The greater the social responsibility orientation of a firm, the greater its strategic social planning.

Participative decision making emphasizes a proactive search for opportunities, participation, analytic decision tools, open communication channels, and participative consensus-based decision making. A participative decision- making orientation is particularly important for strategic social planning as it encourages the collaboration of employees in decision making. For example, a focus on the development of an employee self-governance capability is 
essential to creating a learning organization (Miles \& Creed, 1995). In addition, empirical research finds that it has a positive impact on firm financial performance (Goll \& Sambharya, 1995). Environmental management scholars theorize that the participation of employees is key to an effective environ- mental strategy because it facilitates process innovation (Sharma \& Vredenburg, 1998). Firms in which information flows freely among employees are likely to engage in strategic social planning more effectively than competitors where information is not shared as extensively with employees (Reinhardt, 1999). Thus it is proposed

Hypothesis 9: The greater the participative decision making orientation of the firm, the greater its strategic social planning.

\section{Social Strategy and Value Creation}

Social strategy generates economic value through social projects via strategic social positioning and social planning. The presence of powerful stake- holders and corporate values increase the use of social planning, while the industry competitive environment and firm resources drive strategic social positioning. Generally speaking social strategy creates economic value for the firm via improved firm reputation (Fombrun \& Shanley, 1990), product differentiation (Reinhardt, 1999) or process innovation.

Firms appropriate the economic value generated through social projects when customers pay a premium for the firm's products and services based on its engagement with, and position with respect to specific social and environmental issues. Value is generated through new products or services that incorporate a social attribute or through the development of entirely new markets (Orsato, 2006). Value can also be created when a social action pro- gram, frequently environmental improvement efforts, leads to innovation in firm processes with positive cost reductions (Reinhardt, 1999). Finally, in keeping with resource-dependency theory, social strategy may also lead to more favorable treatment by resource providers and thus allow for greater appropriation of existing value by the firm.

Social positioning may provide additional avenues for value creation. There appears to be a tight link between proactive business strategies and proactive social and environmental strategies (Aragon-Correa, 1998). Although the relationship among proactive business strategy, social positioning, and value creation is unclear, there is evidence that firms can obtain first-mover advantages by making environmental investments before the competition (Nehrt, 1996). 
Hypothesis 10: The greater the strategic social positioning, the greater the ability of the firm to create economic value through its social projects.

Hypothesis 11: The greater the strategic social planning, the greater the ability of the firm to create economic value through its social projects.

\section{Method}

This section is divided into three parts. First, it examines the measures used to operationalize the variables in the model. It then explains the survey method used to collect data. Finally, it discusses partial least squares, which is the statistical method used to analyze the data.

\section{Measures}

The authors developed a survey instrument to measure the twelve basic constructs of value creation, strategic planning, strategic positioning, dynamism, munificence, stakeholder integration, continuous innovation, NGO salience, employee salience, governmental salience, social responsibility orientation, and participative decision-making orientation. A panel of 10 academics and business people established the face validity of the instrument by reviewing it for any items that may have been ambiguous. A small pilot survey was then carried out in order to provide an independent means of establishing the content validity of the measures. The results of this study were consistent with the panel and reinforced confidence in the validity of the measures.

The items for value creation, strategic planning, and strategic position- ing were developed specifically for this study. Dynamism and munificence were measured using items already developed and tested by Sutcliffe and Huber (1998). The items for NGO, employee, and government salience were developed in prior work by Agle et al. (1999). The authors developed items for stakeholder integration and continuous improvement using work by Sharma and Vredenburg (1998). The strategic positioning items were based on Nigh and Meznar's (1995) items of social initiative, by which they meant proaction. The items measuring social responsibility orientation and 
participative decision-making orientation were drawn from the research ofGoll and Zeitz (1991). All the items are found in the appendix. This study used reflective, rather than formative indicators (Diamantopoulos,1999; Diamantopoulos \& Siguaw, 2002). Reflective indicators are mea- sures that are semantically redundant, or collinear with each other and with the construct to which they refer (Ehremberg \& Goodhart, 1976; Kline, 1998). Formative indicators are not semantically redundant or collinear with the construct to which they refer, but they are strongly associated on a multivariate basis with the construct (Diamantopoulos \& Winklhofer, 2001; Petter, Straub, \& Rai, 2007). In other words, the indicators used in this study reflect an unobserved construct (latent variable), and are thus expected to load on the construct in question. An unobserved construct causes the observed measures, referred to as indicators, and also known as manifest variables. The opposite relationship holds for formative indicators. In this study, each of the unobserved constructs gives rise to or "causes" the observed indicators.

\section{Data Collection}

Firms were sampled from the Dicodi database of Spanish firms, published by Equifax Iberica. It consists of a total of almost 50,000 firms throughout the country. The authors sent surveys to the chief executive officers of the

500 largest firms in the Dicodi database, based on both sales and number of employees during April-July 2002. They received 110 responses to the survey, either after the initial mailing or as a result of the follow-up. This number represents a response rate of $21.8 \%$.

In terms of general descriptive data, the sample consisted of 63 firms in the service sector and 47 in the manufacturing sector. The firms came from such diverse industries as commerce, construction, energy, financial services, manufacturing (heavy and light), mining, textiles, tourism, and other services. Firms had an average of 4,261 employees. Average sales amounted to US\$833 million. Nonrespondents were significantly smaller with an average of 2,965 employees and average sales of US\$749 million. In addition, $49 \%$ of nonrespondents were in manufacturing activities, compared to $43 \%$ of respondents. These differences suggest that among large Spanish firms, the largest are more likely to respond. Larger firms may have greater resources to dedicate to answering this type of survey, but may be more likely to have significant CSR programs.

Given these differences between respondents and nonrespondents with respect to size and industrial activity, a concern about nonresponse bias naturally arises. A comparison of the early responders with late responders shows no significant 
difference in participation in social action projects, the use of social strategy, or in competitive environmental factors. In fact, there were no significant differences in the responses to any of the survey questions. Some analysts argue that late responders are similar to nonresponders (Armstrong \& Overton, 1977). The fact that no significant differences in responses were found between early and late responders suggests that non- response bias is not a problem.

There may be a concern about the age of the survey results. Nevertheless, the topic of social strategy in the management literature, as opposed to CSR, is still very new. A review of articles in Proquest Direct that include the phrase "social strategy" since July 2002 through April 2009 indicate that only 22 such articles are available. A similar search of the words "corporate social responsibility" and "Spain" in article abstracts revealed only 21 articles. When the word "strategy" was searched anywhere in the text, the number of articles dropped to five. Social action by Spanish firms of any kind, let along strategic social action, is still a novel phenomenon and thus these data warrant consideration. Since the purpose of this article is not to describe the representative Spanish firm, but to explore a new area of management inquiry, the use of this data is justified.

\section{Data Analysis}

Partial least squares (PLS), a variance-based structural equation modeling technique, is used to examine the hypotheses. PLS is an advanced causal modeling technique that allows the analyst to examine both theory and measures simultaneously (Gefen, Straub, \& Boudreau, 2000; Hulland, 1999). Multiple regression does not permit this kind of holistic approach to a modeling problem. On the other hand, classic structural equation modeling requires compliance with rigorous assumptions that are not warranted by most social science data (Falk \& Miller, 1992; Haenlein \& Kaplan, 2004; Kline, 1998). PLS is particularly useful for exploratory studies, such as in this case, where researchers are developing new ideas (Chin, Marcolin, \& Newsted, 2003; Chin \& Todd, 1995). This method does not establish causality, but only determines "the likelihood of an event given information about other events" (Falk \& Miller, 1992, p. 5). It is especially useful in the situation presented by this article in which some relevant variables may not have been included. For classic structural equation modeling (also known as covariance based), omission of such variables could create problems in connection with model specification and identification in software that implements covariance-based techniques (such as LISREL's), but not so for variance-based modeling techniques like PLS (Gefen et al., 2000). Therefore, given the incipient state of knowledge about value creation 
through corporate social projects, the variance-based structural modeling approach of PLS seemed most appropriate. ${ }^{1}$

\section{Results}

This section is divided into two parts. The first part explores issues of validity and reliability of the measures through PLS using what is referred to as the measurement or outer model. The second part examines the hypotheses through the inner or structural model.

\section{Outer (Measurement) Model}

The results of the measurement model are displayed in Table 2. The reliability of individual items was assessed by examining the loadings for each of the items on the construct. Except for the dynamism construct, all of the loadings were 0.67 or above. A rule of thumb is to only accept loadings of 0.7 or above (Nunnally, 1978; Rosenthal \& Rosnow, 1991), but sometimes lower loadings are permissible, especially in the development of new scales, as in the case of the planning and positioning constructs (Hulland, 1999). In no case should loadings lower than 0.5 be allowed (Hulland, 1999). So the dynamism construct is clearly not a reliable mea- sure; however, all of the other constructs do satisfy the needs for the exploratory kind of research involved in this study.

The convergent validity of the model was assessed by looking at the composite reliability for each construct using the internal consistency mea- sure developed by Fornell and Larcker (1981). The interpretation of this measure is similar to that of Cronbach's alpha, and similarly the 0.70 rule of thumb applies. In all cases, except for dynamism, acceptable levels of composite reliability, indicating convergent validity, were found. Average variance extracted for indicators with proportions greater than 0.50 is generally believed to demonstrate an acceptable level of convergent validity (Robins, Tallman, \& Fladmoe-Lindquist, 2002). All of the constructs, except for dynamism, demonstrated acceptable average variance extracted above the 0.50 level.

Common method variance poses a potential threat to validity in self- administered surveys. Following the lead of other scholars, the design of the instrument sought to diminish the severity of this problem (Christmann, 
Table 2. Measurement Model: Indicator Loadings, Residual Variance, and Variance Extracted for Constructs

\begin{tabular}{|c|c|c|c|c|c|c|}
\hline Construct & Indicator & Loading & SE & $\begin{array}{l}\text { Composite } \\
\text { Reliability }\end{array}$ & AVE & Root Ave \\
\hline \multirow[t]{3}{*}{ Dynamism } & Dyna1 & 0.41 & 0.33 & 0.58 & 0.35 & 0.59 \\
\hline & Dyna2 & 0.87 & 0.31 & & & \\
\hline & Dyna3 & 0.37 & 0.58 & & & \\
\hline \multirow[t]{3}{*}{ Munificence } & Muni1 & 0.88 & 0.03 & 0.85 & 0.66 & 0.81 \\
\hline & Muni2 & 0.78 & 0.07 & & & \\
\hline & Muni3 & 0.74 & 0.08 & & & \\
\hline \multirow{3}{*}{$\begin{array}{l}\text { Stakeholder } \\
\text { Integration }\end{array}$} & Stake1 & 0.91 & 0.02 & 0.92 & 0.80 & 0.89 \\
\hline & Stake2 & 0.88 & 0.03 & & & \\
\hline & Stake3 & 0.89 & 0.03 & & & \\
\hline \multirow{2}{*}{$\begin{array}{l}\text { Continuous } \\
\text { Innovation }\end{array}$} & Cont1 & 0.91 & 0.02 & 0.91 & 0.84 & 0.92 \\
\hline & Cont2 & 0.92 & 0.02 & & & \\
\hline \multirow{3}{*}{$\begin{array}{l}\text { Employee } \\
\text { Salience }\end{array}$} & Emplo1 & 0.84 & 0.04 & 0.89 & 0.74 & 0.86 \\
\hline & Emplo2 & 0.84 & 0.03 & & & \\
\hline & Emplo3 & 0.89 & 0.03 & & & \\
\hline \multirow{3}{*}{$\begin{array}{l}\text { NGO } \\
\text { Salience }\end{array}$} & Ngosa1 & 0.81 & 0.06 & 0.92 & 0.80 & 0.89 \\
\hline & Ngosa2 & 0.93 & 0.02 & & & \\
\hline & Ngosa3 & 0.93 & 0.02 & & & \\
\hline \multirow{3}{*}{$\begin{array}{l}\text { Government } \\
\text { Salience }\end{array}$} & Gover1 & 0.87 & 0.07 & 0.92 & 0.79 & 0.89 \\
\hline & Gover2 & 0.87 & 0.07 & & & \\
\hline & Gover3 & 0.93 & 0.11 & & & \\
\hline \multirow{3}{*}{$\begin{array}{l}\text { Social } \\
\text { Responsibility } \\
\text { Orientation }\end{array}$} & Sro1 & 0.87 & 0.03 & 0.90 & 0.74 & 0.86 \\
\hline & Sro2 & 0.88 & 0.04 & & & \\
\hline & Sro3 & 0.84 & 0.04 & & & \\
\hline \multirow{3}{*}{$\begin{array}{l}\text { Participative } \\
\text { Decision } \\
\text { Making } \\
\text { Orientation }\end{array}$} & Pdo1 & 0.94 & 0.02 & 0.86 & 0.68 & 0.82 \\
\hline & Pdo2 & 0.90 & 0.04 & & & \\
\hline & Pdo3 & 0.60 & 0.14 & & & \\
\hline \multirow{3}{*}{$\begin{array}{l}\text { Social } \\
\text { Positioning }\end{array}$} & Posit1 & 0.85 & 0.02 & 0.79 & 0.55 & 0.74 \\
\hline & Posit2 & 0.67 & 0.09 & & & \\
\hline & Posit3 & 0.70 & 0.09 & & & \\
\hline \multirow{4}{*}{$\begin{array}{l}\text { Social } \\
\text { Planning }\end{array}$} & Plan1 & 0.83 & 0.04 & 0.86 & 0.60 & 0.77 \\
\hline & Plan2 & 0.82 & 0.06 & & & \\
\hline & Plan3 & 0.69 & 0.07 & & & \\
\hline & Plan4 & 0.75 & 0.06 & & & \\
\hline \multirow{6}{*}{$\begin{array}{l}\text { Value } \\
\text { Creation }\end{array}$} & Value1 & 0.77 & 0.06 & 0.91 & 0.63 & 0.79 \\
\hline & Value2 & 0.73 & 0.07 & & & \\
\hline & Value3 & 0.81 & 0.06 & & & \\
\hline & Value4 & 0.72 & 0.09 & & & \\
\hline & Value5 & 0.84 & 0.04 & & & \\
\hline & Value6 & 0.88 & 0.04 & & & \\
\hline
\end{tabular}

Note: AVE is average variance extracted.

2000; Robins et al., 2002). Specifically, the authors avoided implying that one response was preferable to another, made all responses of equal effort, paid attention to item wording, used items 
that were less subject to bias, and provided clear instructions (Nunnally \& Bernstein, 1994, p. 391).

In addition to the preventive actions, a post hoc analysis to determine the presence of potential problems associated with common method variance using Harman's one-factor test was carried out (Podsakoff \& Organ,

1986). This test requires that the researcher do an unrotated principal components factor analysis of the variables in order to assess whether a single factor accounts for more than $50 \%$ of the covariance in the independent and dependent variables. The independent and dependent variables did not load on a single factor and no factor accounted for more than $50 \%$ of the covariance, suggesting that common method variance was not relevant.

Discriminant validity was evaluated by comparing the square root of the average variance extracted (root AVE) for a given construct to the estimated path coefficients. The root AVE scores all exceed the path coefficients, indicating adequate discriminant validity (Hulland, 1999). In addition, discriminant validity may be established by comparing the root $\mathrm{AVE}$ scores to the correlation between the different constructs (Hulland, 1999). In Table 3, the root AVE scores appear in the diagonal elements and the correlations are shown in the off-diagonal elements. The root AVE exceeds the off-diagonal elements for each construct, once again demonstrating that adequate discriminant validity exists.

\section{Inner (Structural) Model}

The path coefficients for the structural model are reported in Table 4. The significance of the path coefficients was assessed using the bootstrapping technique (Nevitt \& Hancock, 2001). The number of resamples used in the

Table 3. Discriminant Validity ${ }^{a}$

\begin{tabular}{|ll|l|l|l|l|l|l|l|l|l|l|l|l|}
\hline & & 1 & 2 & 3 & 4 & 5 & 6 & 7 & 8 & 9 & 10 & 11 & 12 \\
\hline 1. & Dynamism & 0.59 & & & & & & & & & & & \\
\hline 2. & Munificence & 0.44 & 0.81 & & & & & & & & & & \\
\hline 3. & $\begin{array}{l}\text { Stakeholder } \\
\text { Integration }\end{array}$ & 0.15 & 0.25 & 0.89 & & & & & & & & & \\
\hline 4. & $\begin{array}{l}\text { Continuous } \\
\text { Innovation }\end{array}$ & 0.13 & 0.29 & 0.70 & 0.92 & & & & & & & & \\
\hline $\begin{array}{l}5 . \\
6 .\end{array}$ & $\begin{array}{l}\text { Employee } \\
\text { Salience }\end{array}$ & 0.14 & 0.47 & 0.55 & 0.61 & 0.86 & & & & & & & \\
\hline $\begin{array}{l}7 . \\
8 .\end{array}$ & $\begin{array}{l}\text { NGO } \\
\text { Salience }\end{array}$ & 0.20 & 0.39 & 0.45 & 0.41 & 0.45 & 0.89 & & & & & & \\
\hline 9. & $\begin{array}{l}\text { Government } \\
\text { Salience }\end{array}$ & 0.27 & 0.55 & 0.32 & 0.70 & 0.50 & 0.37 & 0.89 & & & & & \\
\hline
\end{tabular}




\begin{tabular}{|c|c|c|c|c|c|c|c|c|c|c|c|c|c|}
\hline & $\begin{array}{l}\text { Social } \\
\text { Responsibility } \\
\text { Orientation }\end{array}$ & 0.19 & 0.35 & 0.48 & 0.55 & 0.51 & 0.72 & 0.44 & 0.86 & & & & \\
\hline $\begin{array}{l}11 . \\
12 . \\
13 .\end{array}$ & $\begin{array}{l}\text { Participative } \\
\text { Decision } \\
\text { Making } \\
\text { Orientation }\end{array}$ & 0.12 & 0.36 & 0.48 & 0.67 & 0.67 & 0.44 & 0.43 & 0.59 & 0.82 & & & \\
\hline $\begin{array}{l}14 . \\
15 .\end{array}$ & $\begin{array}{l}\text { Social } \\
\text { Strategic } \\
\text { Positioning }\end{array}$ & -0.02 & 0.34 & 0.54 & 0.29 & 0.53 & 0.55 & 0.34 & 0.53 & 0.46 & 0.74 & & \\
\hline $\begin{array}{l}16 . \\
17 .\end{array}$ & $\begin{array}{l}\text { Social } \\
\text { Strategic } \\
\text { Planning }\end{array}$ & 0.17 & 0.32 & 0.16 & 0.29 & 0.32 & 0.44 & 0.21 & 0.51 & 0.34 & 0.37 & 0.77 & \\
\hline 18. & $\begin{array}{l}\text { Value } \\
\text { Creation }\end{array}$ & -0.02 & 0.25 & 0.08 & 0.16 & 0.25 & 0.31 & 0.30 & 0.27 & 0.37 & 0.43 & 0.31 & 0.79 \\
\hline
\end{tabular}

a. The root average variance extracted (AVE) scores appear in the diagonal cells and the correlations are shown in the off-diagonal cells.

bootstrapping analysis was set to 200. Bootstrapping is a nonparametric technique in which a resampled set of path coefficients is generated by randomly "shuffling" the original dataset; as one would do with a deck of cards (Fan, 2003). This set of resamples is then used in the estimation of the statistical significance of the path coefficients calculated based on the original dataset (Martin, 2007). As predicted by the central limit theorem, random shuffling of the original dataset creates a normal distribution of path coefficients (Diaconis \& Efron, 1983). From that, a $t$-distribution is obtained, and the statistical significance of each original path coefficient is calculated through the incomplete beta function (Abramowitz \& Stegun, 1965).

Table 4. Structural Model Parameter Estimates

\begin{tabular}{|l|c|c|c|}
\hline Relationship (hypothesis) & $\begin{array}{c}\text { Path } \\
\text { coefficients }\end{array}$ & SE & $\begin{array}{c}\text { P (bootstrap } \\
\text { estimates) }\end{array}$ \\
\hline H1: Dynamism positioning & 0.02 & 0.08 & 0.42 \\
\hline H2: Munifience Positioning & 0.16 & 0.09 & 0.02 \\
\hline H3: Stakeholder integration & 0.10 & 0.11 & 0.18 \\
\hline H4: Continuous innovation & 0.57 & 0.13 & 0.00 \\
\hline H5: Employee Salience & 0.07 & 0.12 & 0.27 \\
\hline H6: NGO salience Planning & 0.18 & 0.13 & 0.05 \\
\hline H7: Government salience & -0.06 & 0.13 & 0.30 \\
\hline H8: Social responsibility & 0.24 & 0.16 & 0.03 \\
\hline H9: Participative Decision & 0.12 & 0.14 & 0.16 \\
\hline H10: Positioning Value & 0.29 & 0.11 & 0.00 \\
\hline H11: Panning Value creation & 0.22 & 0.10 & 0.03 \\
\hline H10: Positioning Value creation & 0.29 & 0.11 & 0.00 \\
\hline H11: Planning Value creation & 0.22 & 0.10 & 0.03 \\
\hline
\end{tabular}


Unlike structural equation modeling for which overall goodness of fit measures exist, no such corresponding goodness-of-fit measures exist for PLS. One can assess goodness of fit by examining the coefficient of determination $\left(R^{2}\right)$ for the endogenous variables: social positioning was 0.50 , for planning 0.25 , and for value creation 0.19. These levels of $R^{2}$ exceeded those reported in other studies such as Birkinshaw, Morrison, and Hulland (1995) as well as the level recommended by Falk and Miller (1992). Hence, there is an adequate fit between the model and the data.

Hypothesis 1 examines the impact of dynamism on strategic social positioning. However the insignificant path coefficient of 0.02 $(p=.42)$ does not permit us to confirm this hypothesis. Hypothesis 2 suggests that munificence positively affects strategic social positioning. The path coefficient $(0.16)$ is significant at the 0.05 level and supports this theoretical expectation. Hypothesis 3 postulates a positive impact of stakeholder integration on strategic social positioning. The path coefficient of 0.10 is insignificant at the 0.05 level, disconfirming the initial expectation. Continuous innovation is also hypothesized to affect strategic social positioning positively. Hypothesis 4 is confirmed as can be seen by the significance of the path coefficient $(0.57, p=.00)$.

Hypotheses 5 to 7 deal with the impact of stakeholder salience on strategic social planning. Hypothesis 5 suggests that employee salience has a positive impact on strategic social planning. The relatively low path coefficient of 0.07 is not significant $(p=.27)$ and thus, the hypothesis is disconfirmed. Hypothesis 6, which relates NGO salience to strategic social planning, is confirmed as seen by the path coefficient of 0.18 , which is significant and positive at the 0.05 level. Hypothesis 7 suggests that government salience also impacts strategic social planning positively. Interestingly, not only is the path coefficient insignificant $(p=.30)$, but the sign is the opposite of what is expected.

Hypotheses 8 and 9 explore the impact of social responsibility orientation and participative decision making orientation, respectively, on strategic social planning. The path coefficient for social responsibility orientation is significant $(p=.03)$, but the path coefficient for participative decision making is not significant $(p=$ .16). These results suggest that, while social responsibility orientation has a significant effect on social planning, participative decision making does not.

Finally, hypotheses 10 and 11 examine the impact of strategic social positioning and strategic social planning on value creation. The path coefficients for both of these variables are significant. The 
path coefficient for strategic social positioning is $0.29(p=.00)$ confirming hypothesis 10 . In the case of hypothesis 11 , regarding the impact of strategic social planning on value creation, the path coefficient of 0.22 is also significant $(p=.03)$. Thus, both of these hypotheses are confirmed suggesting that value creation occurs via social positioning as well as social planning.

\section{Discussion}

This article begins to identify the conditions under which social action may create economic value. As regards competitive strategy itself, both social strategic planning and social strategic positioning create value for the firm. However, the effect of positioning on value creation is even greater than the effect of planning. One possible explanation for this result is that many firms as yet have not moved to strategic planning of social projects, while recognizing that a strategic competitive position is advantageous. Once again, firm uncertainty as to how to pursue competitive advantage through social projects appears to have a significant impact. Future research should examine the extent to which increased experience in social strategy is related to value creation through social strategic planning and social strategic positioning.

In the case of strategic social positioning, the relevant variables deal with the market environment as well as the nature of the firm's resources. A munificent environment and the capability of continuous innovation lead to greater strategic positioning. Surprisingly dynamism did not have a significant relationship to strategic social positioning. This result may be due to the low validity of this previously validated construct. One possible explanation is that dynamism appears to be variously interpreted by firms in environments with multiple stakeholders, with the result that some firms seek entrepreneurial opportunities while others experience threat rigidity (Koka et al., 2006).

In terms of stakeholders, it appears that salient NGO stakeholders have a strong influence on the tendency to use planning-based social strategy- more so than employees or the government. In addition, firms that place a high value for social responsibility are also more likely to engage in social planning.

Although the competitive strategy literature is a logical place to begin to understand social strategy, it is only a beginning and this study drives home the necessity of undertaking research of traditional strategy variables to see if they operate similarly in the context of value creation via social strategy. This article explores new terrain and thus the traditional variables like dynamism may not always act as one would expect. Once again, it appears that firms variously interpret market and nonmarket variables in what 
are relatively new approaches to creating economic value.

\section{Conclusions}

This concluding section explains the main contributions and then the limitations of this article. There are suggestions for future research.

\section{Main Contributions}

This article has argued that certain sets of market conditions, resources, values, and stakeholder salience lead to different approaches to social strategy. Specifically, planning and positioning create value through their social projects. Thus, research into social strategy moves the CSR literature beyond a one-size-fits-all approach to a careful examination of the conditions under which corporate social projects will create value for the firm.

This article makes a number of important contributions to the theoretical literature. First, it shows how social action may be integrated into business strategy and refocuses the CSR-CFP on the conditions under which corporate social action projects can create economic value for the firm. Second, it shifts attention from the highly contested concept of CSR to the more instrumental concept of social strategy. Finally, the article uses the very rich concept of economic value creation instead of the narrower concept of financial performance, usually measured with account-based or market-based indicators.

Using a data set of large Spanish firms, the article makes an empirical contribution by measuring and validating the constructs for two firm resources-stakeholder integration and continuous innovation-as well as the constructs of social planning and value creation. The empirical setting is certainly an interesting one and worthy of note as a place where relatively few studies of CSR or social strategy have taken place.

In addition to theoretical and empirical contributions, there are important implications for management practice. The research helps managers to understand the importance of munificence and continuous innovation to the use of social positioning. On the other hand, a strong CSR orientation and high NGO salience is highly related to the use of social planning. Both of these strategic approaches to social projects can help the firm create value.

In so doing, social strategy extends the resource-based view by acknowledging that firm resources are part of and emerge from all firm activities. Social strategy provides a theoretic framework that helps situate recent work on philanthropy and moral capital (Godfrey, 2005) and corporate social performance and customer brand identification (Schuler \& Cording, 2006) by demonstrating that 
the salience of nonmarket stakeholders, like NGOs, contributes to value creation. Moreover, social strategy enriches the literature on resource dependency by applying it to both market conditions of munificence and dependence on nonmarket stakeholders.

\section{Limitations}

Certainly, this exploratory study does not represent the final word. It suffers from the inevitable weaknesses that such studies entail: the sample is representative of only Spain's largest firms, while some of the measures do not have an established track record of reliability.

Given that this study focused on large firms, other strategies may be more appropriate for smaller, less-well positioned firms. For example, in low munificent markets, strategic social positioning may be a less costly alternative to more expensive strategies. Social marketing may be engaged in. Finally, relationships found in Spanish firms may not apply to firms operating in other national or multinational contexts (Husted \& Allen, 2007; Matten \& Moon, 2008). Further research is needed. 


\section{Suggestions for Future Research}

Future research into the relationship between corporate resources and non- market opportunities should seek to assist in providing managers with stronger arguments for when and under what conditions corporate social strategies will benefit the firm. Of particular importance is how resources and corporate values may mutually reinforce each other to create heterogeneous, firm-specific competitive advantages.

For example, one would expect that the capability of continuous innovation (strategic positioning) to be accompanied by the value of social responsibility orientation (strategic planning). This study only hints at such complementarities. However, as indicated in the discussion of the value creation model, the large number of relevant variables increases complexity sufficiently that significantly more testing and data are needed to study carefully possible interactions as well as potential moderating and mediating variables. One of the principal challenges of future research is to work through that complexity to describe possible value creation paths that incorporate market and nonmarket strategies (Baron, 1995).

Future research might also look to recent work in political strategy (Bonardi, Hillman, \& Keim, 2005) and environmental strategy (Russo \& Fouts, 1997) for insights into how firms manage specific areas of nonmarket strategy. Institutional theory may also be required to examine the extent to which social positioning is a result of mimetic rather than strategic action (DiMaggio \& Powell, 1983). In effect, the approach taken in this article posits a reformulation of the theory of the firm in which nonmarket social action (social strategy) may be integrated into market strategylong an objective of supporters of the stakeholder theory of the firm (Freeman, 1984). As argued above, this requires broadening the research agenda in order to specify the contingencies that shape corporate social strategies.

Accordingly, one key area for future research would be to test these results against other possible models and methodologies. Much more work needs to be done to identify other variables that are involved in the mediating chain linking corporate social projects to value creation. Of particular interest as regards resource dependency is the question of how firm behavior in market and nonmarket networks is constrained by different actors as firms

pursue competitive advantage via social initiatives. Certainly, additional stakeholders, capabilities, values, and market conditions need to be studied. Nevertheless, this article demonstrates one way in which research in this area may proceed. 


\section{Appendix}

\section{Survey Items}

Value creation: Please indicate the extent to which the following reasons for participating in social programs coincide with those of your firm (response is based on a 5-point Likert-type scale from not at all to completely)

Value1: Influence the purchasing decisions of customers Value2: Develop new businesses with social objectives Value3: Obtain new customers Value4: Increase profitability

Value5: Develop new products or services Value6: Open new markets

Social planning: To what extent do each of the following statements apply to your firm (response is based on a 5-point Likert-type scale from totally disagree to totally agree).

Plan1: Your firm has a definite plan for the development of social initiatives. Plan2: Your firm measures the results of its social initiatives.

Plan3: Your firm enables employees to dedicate part of their work time to participate in social initiatives.

Plan4: What range best represents the percentage of investment in social initiatives over total sales? $0 \%$, less than $1 \%, 1 \%$ to $2 \%, 2 \%$ to $5 \%$, more than $5 \%$.

Social positioning: For Posit1 and Posit2, to what extent do each of the following statements apply to your firm (response is based on a 5point Likert-type scale from not at all to completely).

Posit1: We are usually among the first in adapting our corporate practices to changing social expectations.

Posit2: Our corporate practices exceed current regulatory norms. Posit3: Compared to other firms in your industry, how do you characterize your spending on social initiatives? (Responses based on a

5-point Likert-type scale from much less to much more).

Dynamism: For each of the following conditions, please evaluate the extent to which they apply to your firm (response is based on a 5point Likert- type scale from not at all to a great deal). 
Dyna1: The demands and preferences of customers are relatively stable in your industry.

Dyna2: Income and profits are relatively stable in your industry.

Dyna3: The firm faces frequent changes due to the incorporation of new technologies.

Munificence: For each of the following conditions, please evaluate the extent to which they apply to your firm (response is based on a 5point Likert- type scale from not at all to a great deal).

Muni1: The demand for products/services in our principal industry is growing and will continue to grow.

Muni2: Capital investments in our principal industry are growing and will continue to grow.

Muni3: The profit margins in our principal industry are growing and will continue to grow.

Employee salience: Please indicate the extent to which you agree with the following statements (response is based on a 5-point Likerttype scale from Totally disagree to totally agree).

Empsal1: Employees deserve a great deal of consideration from our organization.

Empsal2: Our top management team dedicates a great deal of time and attention to our employees.

Empsal3: Satisfying the demands of employees is important to our top management team.

NGO salience: Please indicate the extent to which you agree with the following statements (response is based on a 5-point Likert-type scale from Totally disagree to totally agree).

Ngosal1: Nongovernmental organizations deserve a great deal of consideration from our organization.

Ngosal2: Our top management team dedicates a great deal of time and attention to NGOs.

Ngosal3: Satisfying the demands of NGOs is important to our top management team. 
Government salience: Please indicate the extent to which you agree with the following statements (response is based on a 5-point Likert-type scale from Totally disagree to totally agree).

Govsal1: Governmental institutions deserve a great deal of consideration from our organization.

Govsal2: Our top management team dedicates a great deal of time and attention to governmental institutions.

Govsal3: Satisfying the demands of governmental institutions is impor- tant to our top management team.

Stakeholder integration: Compared to other firms, evaluate your firm's abilities (response is based on a 5-point Likert-type scale from poor to excellent).

Stake1: The ability of our firm to collaborate with stakeholders (interest groups: customers, suppliers, etc.) in developing solutions to social problems is...

Stake2: The ability of our firm to explain its point of view to the com- munity and its stakeholders is...

Stake3: The ability of our firm to handle new problems effectively through dialogue our stakeholders is...

Continuous innovation: Compared to other firms, evaluate your firm's abilities (response is based on a 5-point Likert-type scale from poor to excellent).

Cont1: The ability of our firm to identify opportunities for social action from changes in the social environment is....

Cont2: The ability of our firm to innovate and simultaneously improve its operations and its social impact is....

Social responsibility orientation: Please indicate the degree to which you agree with the following statements (response is based on a 5-point Likert- type scale from totally disagree to totally agree).

Sro1: Corporate top management values monitoring new opportunities which can enhance the company's ability to solve social problems.

Sro2: The corporation believes in performing in a manner consistent with the philanthropic and charitable expectations of society. 
Sro3: The policies of the firm emphasize that its philanthropic behavior is a useful measure of corporate performance.

Participative decision making orientation: Please indicate the degree to which you agree with the following statements (response is based on a 5-point Likert-type scale from totally disagree to totally agree).

Pdo1: Top management is convinced of the long-term strategic importance of adopting participative decision making at both middle and senior management levels.

Pdo2: The company's philosophy emphasizes participative consensus- building decision making based on consensus, followed by feed- back of results of change for group evaluation and further action.

Pdo3: The company's philosophy emphasizes reliance on responsible executives to make all product or service-related decisions concerning level of operations, marketing, etc.

\section{Declaration of Conflicting Interests}

The author(s) declared no potential conflicts of interest with respect to the research, authorship, and/or publication of this article.

\section{Funding}

The author(s) disclosed receipt of the following financial support for the research, authorship, and/or publication of this article: Bryan Husted received partial support from Grant \#33661-D of the Consejo Nacional de Ciencia y Tecnología of the Mexican Federal Government as well as research support from the Alumni Association Chair in Business Ethics of the Instituto de Empresa in Madrid, Spain.

\section{Note}

1. In addition to the variables of theoretical interest, CSR researchers have emphasized the need to control for risk, firm size, and industry (Cochran \& Wood, 1984; Waddock \& Graves, 1997). In order to test the possible impact of these variables, the authors performed three ordinary least squares (OLS) multiple regressions using each of these variables as independent variables in the regression analyses. Firm size was measured by the number of employees. 
Industries were measured as dummy variables according to the Spanish industrial classification system. Risk was measured using the ratio of debt to assets. Preliminary analyses confirmed that the assumptions for OLS regression were fulfilled. The three regressions confirmed the results using the PLS analyses and demonstrated that none of the control variables was significant. Thus, one can conclude that firm size, industry classification, and firm risk do not affect these results.

\section{References}

Abramowitz, M., \& Stegun, I. (1965). Handbook of mathematical functions, with for- mulas, graphs, and mathematical tables. New York, NY: Dover.

Agle, B. R., Mitchell, R. K., \& Sonnenfeld, J. A. (1999). Who matters to CEOs? An investigation of stakeholder attributes and salience, corporate performance, and CEO values. Academy of Management Journal, 42, 507-525.

Albert, S., \& Whetten, D. A. (1985). Organizational identity. In L. L. Cummings \& B. M. Staw (Eds.), Research in organizational behavior (vol. 7, pp. 263-295). Greenwich, CT: JAI Press.

Aldrich, H. E. (1979). Organizations and environments. Englewood Cliffs, NJ: Prentice-Hall.

Alvesson, M., \& Berg, P. O. (1992). Corporate culture and organizational symbolism: An overview. Berlin: Walter de Gruyter.

Andrews, K. R. (1987). The concept of corporate strategy (3rd ed.). Homewood, IL: Irwin.

Ansoff, H. I. (1991). Critique of Henry Mintzberg's "The design school: Recon- sidering the basic premises of strategic management." Strategic Management Journal, 12, 449-461.

Aragon-Correa, J. A. (1998). Strategic proactivity and firm approach to the natural environment. Academy of Management Journal, 41, 556-567.

Armstrong, J., \& Overton, T. (1977). Estimating nonresponse bias in mail surveys. Journal of Marketing Research, 18, 396-402.

Bansal, P. (2005). Evolving sustainably: A longitudinal study of corporate sustainable Development. Strategic Management Journal, 26, 197-218.

Barney, J. (1986). Organizational culture: Can it be a source of sustained competitive advantage? Academy of Management Review, 11, 656-665. 
Barney, J. (1991). Firm resources and sustained competitive advantage. Journal of Management, 17, 99-120.

Barney, J., Wright, M., \& Ketchen, Jr., D. J. (2001). The resourcebased view of the firm: Ten years after 1991. Journal of Management, 27, 625-641.

Baron, D. P. (1995). Integrated strategy: Market and nonmarket components. California Management Review, 37(2), 47-65.

Berman, S. L., Wicks, A. C., Kotha, S., \& Jones, T. M. (1999). Does stakeholder orientation matter? The relationship between stakeholder management models and firm financial performance. Academy of Management Journal, 42(5), 488-506.

Bettis, R. A., \& Prahalad, C, K. (1986). The dominant logic: A new linkage between diversity and performance. Strategic Management Journal, 7, 485-502.

Birkinshaw, J., Morrison, A., \& Hulland, J. (1995). Structural and competitive determinants of a global integration strategy. Strategic Management Journal, 16, 637-655.

Bonardi, J. P., Hillman, A. J., \& Keim, G. D. (2005). The attractiveness of political markets: Implications for firm strategy. Academy of Management Review, 30, 397-413.

Burke, L., \& Logsdon, J. M. (1996). How corporate social responsibility pays off. Long Range Planning, 29, 495-502.

Castrogiovanni, G. J. (1991). Environmental munificence: A theoretical assessment. Academy of Management Review, 16, 542-565.

Castrogiovanni, G. J. (2002). Organization task environments: Have they changed fundamentally over time? Journal of Management, 28, 129-150.

Chandler, A. (1962). Strategy and structure. Cambridge, MA: MIT Press.

Chin, W. W., \& Todd, P. A. (1995). On the use, usefulness, and ease of use of structural equation modeling in MIS research: A note of caution. MIS Quarterly, 19, 237-247.

Chin, W. W., Marcolin, B. L., \& Newsted, P. R. (2003). A partial least squares latent variable modeling approach for measuring interaction effects: Results from a Monte Carlo simulation study and an electronic-mail emotion/adoption study. Information Systems Research, 14, 189-218.

Christmann, P. (2000). Effects of "best practices" of environmental management on cost advantage: The role of complementary assets. Academy of Management Journal, 43, 663-680. 
Clarkson, M. B. E. (1995). A stakeholder framework for analyzing and evaluating corporate social performance. Academy of Management Review, 20, 92-117.

Cleland, D. I., \& King, W. R. (1988). Project management handbook (2nd ed.). NewYork, NY: Van Nostrand Reinhold.

Cochran, P. L., \& Wood, R. A. (1984). Corporate social responsibility and financial performance. Academy of Management Journal, 27, 42-56.

Daniel, A. L. (1992). Strategic planning: The role of the chief executive. Long Range Planning, 25(2), 97-104.

Delmas, M., Russo, M. V., \& Montes-Sancho, M. J. (2007). Deregulation and envi- ronmental differentiation in the electric utility industry. Strategic Management Journal, 28, 189-209.

Dess, G., \& Beard, D. (1984). Dimensions of organizational task environments. Administrative Science Quarterly, 29, 52-73.

Diaconis, P., \& Efron, B. (1983). Computer-intensive methods in statistics. Scientific American, 249(1), 116-130.

Diamantopoulos, A. (1999). Export performance measurement: Reflective versus formative indicators. International Marketing Review, 16, 444-457.

Diamantopoulos, A., \& Siguaw, J. A. (2002). Formative vs. reflective indicators in measure development: Does the choice of indicators matter? (Working Paper). Cornell University, Ithaca, NY: School of Hotel Administration.

Diamantopoulos, A., \& Winklhofer, H. (2001). Index construction with formative indicators: An alternative scale development. Journal of Marketing Research, 37, 269-177.

DiMaggio, P. J., \& Powell, W. (1983). The iron cage revisited: Institutional isomor- phism and collective rationality in organizational fields. American Sociological Review, 48, 147-160.

Ehremberg, A. S. C., \& Goodhart, G. J. (1976). Factor analysis: Limitations and alternatives. Cambridge, MA: Marketing Science Institute.

Eisenhardt, K., \& Martin, J. A. (2000). Dynamic capabilities: What are they? Strate- gic Management Journal, 21, 1105-1121.

Falk, R. F., \& Miller, N. B. (1992). A primer for soft modeling. Akron, $\mathrm{OH}$ : University of Akron Press.

Fan, X. (2003). Using commonly available software for bootstrapping in both sub- stantive and measurement analyses. Educational and Psychological Measure- ment, 63(1), 24-50.

Fombrun, C., \& Shanley, M. (1990). What's in a name? Reputation building and cor- porate strategy. Academy of Management 
Journal, 33, 233-258.

Fornell, C., \& Larcker, D.F. (1981). Evaluating structural equation models with unob- servable variables and measurement error. Journal of Marketing Research, 18(1), 39-50.

Freeman, R. E. (1984). Strategic management: A stakeholder approach. Boston, MA: Pitman.

Frooman, J. (1999). Stakeholder influence strategies. Academy of Management Review, 24, 191-205.

Garriga, E., \& Mele, D. (2004). Corporate social responsibility theories: Mapping the territory. Journal of Business Ethics, 53(12), 51-71.

Geertz, C. (1973). The interpretation of cultures: Selected essays. New York, NY: Basic Books.

Gefen, D., Straub, D. W., \& Boudreau, M.-C. (2000). Structural equation modeling and regression: Guidelines for research practice. Communications of the AIS, 4(7), 1-76.

Godfrey, P. (2005). The relationship between corporate philanthropy and share- holder wealth: A risk management perspective. Academy of Management Review, 30, 777-798.

Goll, I., \& Rasheed, A. A. (2004). The moderating effect of environmental munificence and dynamism on the relationship between discretionary social responsibility and firm performance. Journal of Business Ethics, 49, 41-54.

Goll, I., \& Sambharya, R. B. (1995). Corporate ideology, diversification and firm performance. Organization Studies, 16, 823-846.

Goll, I., \& Zeitz, G. (1991). Conceptualizing and measuring corporate ideology.

Organization Studies, 12, 191-207.

Grant, R. M. (1996). Toward a knowledge-based theory of the firm. Strategic Management Journal, 17, 109-122.

Grant, R. M. (1999). Contemporary strategy analysis. Malden, MA: Blackwell. Griffin, J. J., \& Mahon, J. F. (1997). The corporate social performance and corporate financial performance debate: Twenty-five years of incomparable research. Business \& Society, 36, 5-31.

Haenlein, M., \& Kaplan, A. M. (2004). A beginner's guide to partial least squares analysis. Understanding Statistics, 3, 283-297.

Hamel, G., \& Prahalad, C. K. (1989). Strategic intent. Harvard Business Review, 67(3), 63-76.

Hart, S. L., \& Sharma, S. (2004). Engaging fringe stakeholders for 
competitive imagination. Academy of Management Executive, 18(1), 7-18.

Henriques, I., \& Sadorsky, P. (1999). The relationship between environmental commitment and managerial perceptions of stakeholder importance. Academy of Management Journal, 42, 87-99.

Hillman, A. J., \& Keim, G. D. (2001). Shareholder value, stakeholder management, and social issues: What's the bottom line? Strategic Management Journal, 22, 125-139. Hulland, J. (1999). Use of partial least squares (PLS) in strategic management research: A review of four recent studies. Strategic Management Review, 20, 195-204.

Husted, B. W., \& Allen, D. B. (2007). Corporate social strategy in multinational enterprises: Antecedents and value creation. Journal of Business Ethics, 74, 345-361.

Kaplan, R., \& Norton, D. (1996). Balanced scorecard: Translating strategy into action. Cambridge, MA: Harvard Business School Press.

Kanter, R. M. (1999). From spare change to real change. Harvard Business Review, 77(3), 122-132.

Keats, B. W., \& Hitt, M. A. (1988). A causal model of linkages among environmental dimensions. Academy of Management Journal, 31, 570-598.

King, A. (2007). Cooperation between corporations and environmental groups: A transaction cost perspective. Academy of Management Review, 32, 889-900.

Kline, R. B. (1998). Principles and practice of structural equation modeling. New York, NY: The Guilford Press.

Kluckhohn, C. (1951). Values and value-orientations in the theory of action. In Parsons, T., \& Shils, E. A. (Eds.), Toward a general theory of action (pp. 388-433). Cambridge, MA: Harvard University Press.

Koka, B., Madhaven, R., \& Prescott, J. E. (2006). The evolution of interfirm networks: Environmental effects on patterns of network change. Academy of Management Review, 31, 721-737.

Lieberman, M. B., \& Montgomery, D. B. (1988). First-mover advantages. Strategic Management Journal, 9(S1), 41-58.

Liedtka, J. M. (2000). In defense of strategy as design. California Management Review, 42(3), 8-30.

Margolis, J. D., \& Walsh, J. P. (2001). People and profits? The search for a link between a firm's social and financial performance. Mahwah, NJ: Lawrence Erlbaum.

Martin, M. A. (2007). Bootstrap hypothesis testing for some common 
statistical problems: A critical evaluation of size and power properties. Computational Statistics \& Data Analysis, 51, 63216342.

Matten, D., \& Moon, J. (2008). "Implicit" and "explicit" CSR: A conceptual framework for a comparative understanding of corporate social responsibility. Academy of Management Review, 33, 404-424.

McWilliams, A., \& Siegel, D. (2000). Corporate social responsibility and financial performance: Correlation or misspecification? Strategic Management Journal, 21, 603-609.

McWilliams, A., \& Siegel, D. (2001). Corporate social responsibility: A theory of the firm perspective. Academy of Management Review, 26, 117-127.

Menon, A., \& Menon, A. (1997). Enviropreneurial marketing strategy: The emergence of corporate environmentalism as market strategy. Journal of Marketing, 61, 51-67.

Meznar, M. B., \& Nigh, D. (1995). Buffer or bridge? Environmental and organizational determinants of public affairs activities in American firms. Academy of Management Journal, 38, 975-996.

Miller, D. (1987). The structural and environmental correlates of business strategy. Strategic Management Journal, 8, 55-76.

Miller, D., \& Friesen, P. H. (1983). Strategy-making and environment: The third link. Strategic Management Journal, 4, 221-325.

Mintzberg, H. (1990). The design school: Reconsidering the basic premises of strategic management. Strategic Management Journal, 11, 171-195.

Mitchell, R. K., Agle, B. R., \& Wood, D. J. (1997). Toward a theory of stakeholder identification and salience: Defining the principle of who and what really counts. Academy of Management Review, 22, 853-886.

Moran, P., \& Ghoshal, S. (1999). Markets, firms, and the process of economic devel- opment, Academy of Management Review, 24, 390-412.

Muller, A., \& Kolk, A. (2010). Extrinsic and intrinsic drivers of corporate social performance: Evidence from foreign and domestic firms in Mexico. Journal of Management Studies, 47(1), 1-26.

Nehrt, C. (1996). Timing and intensity effects of environmental investments. Strategic Management Journal, 17, 535-547.

Nevitt, J., \& Hancock, G. R. (2001). Performance of bootstrapping approaches to model test statistics and parameter standard error 
estimation in structural equation modeling. Structural Equation Modeling, 8, 353-377.

Nunnally, J. C. (1978). Psychometric theory. New York, NY: McGrawHill.

Nunnally, J. C., \& Bernstein, I. H. (1994). Psychometric theory (3rd ed.). New York, NY: McGraw-Hill.

Orlitzky, M. O., Schmidt, F. L., \& Rynes, S. L. (2003). Corporate social and financial performance: A meta-analysis. Organization Studies, 24, 403-442.

O'Reilly III, C. A., \& Pfeffer, J. (2000). Hidden value: How great companies achieve extraordinary results with ordinary people. Boston, MA: Harvard Business School Press.

Orsato, R. (2006). Competitive environmental strategies: When does it pay to be green? California Management Review, 48(2), 127143.

Palmer, K. L., Oates, W. E., \& Portney, P. R. (1995). Tightening environmental standards: The benefit-cost or the no-cost paradigm? Journal of Economic Perspectives, 9, 119-132.

Petter, S., Straub, D., \& Rai, A. (2007). Specifying formative constructs in information systems research. MIS Quarterly, 31, 623-656.

Peteraf, M. A. (1993). The cornerstones of competitive advantage: A resource-based view. Strategic Management Journal, 14, 179191.

Pfeffer, J., \& Salancik, G. R. (1978). The external control of organizations: A resource dependence perspective. New York, NY: Harper \& Row.

Podsakoff, P. M., \& Organ, D. W. (1986). Self-reports in organizational research: Problems and prospects. Journal of Management, 12, 531-44.

Porter, M. E. (1980). Competitive strategy. New York, NY: The Free Press.

Porter, M. E. (1985). Competitive advantage: Creating and sustaining superior performance. New York, NY: Free Press.

Porter, M. E., \& Kramer, M. R. (2011). Creating shared value. Harvard Business Review, 89(1/2), 62-77.

Priem, R. L., \& Butler, J. E. (2001). Is the "resource-based view" a useful perspective for strategic management research? Academy of Management Review, 26, 22-41. Quinn, J. B. (1980). Strategies for change: Logical incrementalism. Homewood, IL: Irwin. 
Reinhardt, F. (1999). Market failure and the environmental policies of firms: Eco- nomic rationales for "beyond compliance" behavior. Journal of Industrial Ecol- ogy, 3(1), 9-21.

Robins, J. A., Tallman, S., \& Fladmoe-Lindquist, K. (2002). Autonomy and dependence of international cooperative ventures: An exploration of the strategic performance of U.S. ventures in Mexico. Strategic Management Journal, 23, 881-901.

Rosenthal, R., \& Rosnow, R.L. (1991). Essentials of behavioral research: Methods and data analysis. Boston, MA: McGraw Hill.

Rowley, T. (1997). Moving beyond dyadic ties: A network theory of stakeholder influences? Academy of Management Review, 22, 887-910.

Rowley, T., \& Berman, S. (2000). A brand new brand of corporate social performance. Business \& Society, 39, 397-418.

Russo, M. V., \& Fouts, P. A. (1997). A resource-based perspective on corporate environmental performance and profitability. Academy of Management Journal, 40, 534-559.

Savage, G. T., Nix, T. W., Whitehead, C. J., \& Blair, J. D. (1991). Strategies for assessing and managing organizational stakeholders. The Executive, 5(2), 61-75.

Schuler, D. A., \& Cording, M. P. (2006). A corporate social performance-corporate financial performance behavioral model for consumers. Academy of Management Review, 31, 540-558.

Schumpeter, J. A. (1934). The theory of economic development. Cambridge, MA: Harvard University Press.

Sharma, S., \& Vredenburg, H. (1998). Proactive corporate environmental strategy and the development of competitively valuable environmental capabilities. Strategic Management Journal, 19, 729-753.

Staw, B. W., \& Szwajkowski, E. (1975). The scarcity-munificence component of organization environments and the commission of illegal acts. Administrative Science Quarterly, 20, 345-54.

Sutcliffe, K., \& Huber, G. (1998). Firm and industry determinants of executive perceptions of the environment. Strategic Management Journal, 19, 793-809.

Teece, D. J., Pisano, G., \& Shuen, A. (1997). Dynamic capabilities and strategic management. Strategic Management Journal, 18, 509-533.

Trice, H. M., \& Beyer, J. M. (1993). The cultures of work organizations. Englewood Cliffs, NJ: Prentice Hall.

Tushman, M. L., \& Anderson, P. (1986). Technological discontinuities 
and organizational environments. Administrative Science Quarterly, 31, 439-465.

Waddock, S. A., \& Graves, S. B. (1997). The corporate social performance-financial performance link. Strategic Management Journal, 18, 303-319.

Wernerfelt, B. (1984). A resource-based view of the firm.

Strategic Management Journal, 5, 171-180. 